\title{
Effect of organic matter addition on the solubility of arsenic in soil and uptake by rice: a field-scale study
}

\author{
Ji-Hyock Yoo ${ }^{1}$ (]) $\cdot$ Dan-Bi Kim $^{1} \cdot$ Won-Il Kim² ${ }^{2}$ (D) Sung-Chul Kim ${ }^{3}$

\section{유기물 시용이 토양 내 비소의 용해도와 벼의 비소 흡수에 미치는 영향}

\author{
류지혁 ${ }^{1}$ 김단비 ${ }^{1}$ - 김원일 ${ }^{2}$ 김성철 ${ }^{3}$
}

Received: 18 October 2021 / Accepted: 16 November 2021 / Published Online: 31 December 2021

(C) The Korean Society for Applied Biological Chemistry 2021

\begin{abstract}
A field-scale study was conducted to evaluate the effect of organic matter amendments on the solubility of arsenic (As) in paddy soil and uptake by rice. Six organic matter (rice bran, rice straw, pig/cattle/fowls manure compost and swine liquid manure) were added to two polluted soils with high As (53 mg $\mathrm{kg}^{-1}$ ) and low As concentration ( $28 \mathrm{mg} \mathrm{kg}^{-1}$ ), and changes in soil solution constituents was monitored. The mean As concentrations in soil solution from the high As soil with rice bran, pig manure compost and swine liquid manure addition were significantly higher (0.61-1.15 $\left.\mathrm{mg} \mathrm{L}^{-1}\right)$ than that of the control (0.42-0.66 mg $\left.\mathrm{L}^{-1}\right)$. Regression between $\mathrm{As}$ and $\mathrm{Fe}$ in soil solution indicated that As was attributable to reductive dissolution of $\mathrm{Fe}$ (hydr)oxides and it was driven by organic matter addition. Mean As concentrations in brown rice from the high As soil were 0.35-0.46 $\mathrm{mg} \mathrm{kg}{ }^{-1}$, above the maximum safety level of inorganic As $(0.35$
\end{abstract}

\section{Ji-Hyock Yoo $(\bowtie)$}

E-mail: idisryu@korea.kr

Sung-Chul Kim $(\square)$

E-mail: sckim@cnu.ac.kr

${ }^{1}$ Department of Agro-Food Safety, National Institute of Agricultural Sciences, Wanju 55365, Republic of Korea

${ }^{2}$ Eco-Friendly Agri-Bio Research Center, Gokseong 57510, Republic of Korea

${ }^{3}$ College of Agriculture and Life Sciences, Chungnam National University, Daejeon 34134, Republic of Korea

This is an Open Access article distributed under the terms of the Creative Commons Attribution Non-Commercial License (http://creativecommons. org/licenses/by-nc/3.0/) which permits unrestricted non-commercial use, distribution, and reproduction in any medium, provided the original work is properly cited. $\mathrm{mg} \mathrm{kg}^{-1}$ ), and tended to be higher in organic matter amended soils than that of the control. The significant correlation between grain As and soil solution As was not observed and it was probably attributable to As tolerance of rice causing the reduction of As uptake and/or translocation to grain. However, considering the significant As release in soil solution from the high As soil and the tendency of grain As elevation after organic matter addition, it is needed to be cautious for food safety when amending organic matter to paddy soil with high As concentration.

Keywords Arsenic $\cdot$ Organic matter $\cdot$ Rice $\cdot$ Soil $\cdot$ Solubility

\section{서 론}

비소는 미국 독성물질및질병등록국(Agency for Toxic Substances and Disease Registry, ATSDR)에서 관리대상물질 1순위로 지정, 관리하며 국제암연구소(International Agency for Research on Cancer, IARC)는 무기비소를 인체발암물질(Group 1)로 분류하 고 있다[1]. 국내 유통 쌀(백미) 1,401건에 대해 농촌진흥청, 식 품의약품안전처 및 농림축산식품부가 합동으로 실시한 무기비 소 오염도 조사(2013-2015년) 결과 무기비소의 평균 함량은 $0.06 \mathrm{mg} \mathrm{kg}^{-1}\left(0.01-0.16 \mathrm{mg} \mathrm{kg}^{-1}\right)$ 으로 쌀 섭취를 통한 위해수준 이 인체노출안전기준(Provisional Tolerable Weekly Intake, $\mathrm{PTWI}$ )의 $10 \%$ 를 초과하였으며, 쌀에 대한 비소 안전관리의 필 요성에 따라 쌀의 국내 무기비소 기준은 $0.2 \mathrm{mg} \mathrm{kg}^{-1}$ 으로 설정 되었다[2,3].

논토양에서 쌀로의 비소 전이는 사람이 고독성 물질에 노출 되는 주요한 경로이다[4]. 2015년 기준 전국에 산재하는 2,084 개소의 폐금속 광산 중 수질-토양 오염 등의 광해를 발생하는 
광산은 1,217 개로 광해관리공단은 비소 및 중금속의 토양오염 이 확인된 734개 폐광산 지역의 농경지에 대해 2007년부터 토 양개량.복원 사업을 추진중이며 2019년까지 약 $1,267 \mathrm{ha}$ 의 농 경지에 대한 개량.복원을 완료하였다[5]. 광해의 영향을 받은 폐금속 광산 지역의 농경지는 비소에 의한 오염이 일반적이며 충청도 및 전라남도의 11 개 폐금속 광산 지역 농경지에 대한 중금속 오염도 조사 결과, 비소 오염의 빈도가 가장 높았고 조 사한 223 개 필지 중 약 $23 \%$ 에 해당하는 52 개 필지가 비소의 토양오염우려기준을 초과하였으며 이 중 16 개 필지는 대책기준 을 초과하였다[6].

퇴비 등의 유기물 시용은 농경지 토양의 물리화학성을 개선 하고 작물 생육에 필요한 양분을 공급하는 한편, 비소의 이동 에 중요한 역할을 한다[7]. 논토양에서 미생물이 유기물을 탄소 원으로 이용하고 산소를 소모하면 산화환원전위(Eh)가 낮아지 면서[8] 철 (수)산화물의 환원적 가용화가 일어나 고상에 결합 되어 있던 비소가 용출되며[9-13] 환원의 원동력은 유기탄소이 다[14]. 철 (수)산화물로부터 비소의 용출은 $\mathrm{Eh}-100 \mathrm{mV}$ 미만 에서 촉진되며[15] 담수 조건에서 용해된 비소는 벼에 흡수되 고 알곡에 축적되어[16] 유기물 시용에 따른 현미의 비소 농도 가 무시용구보다 약 2 배 높은 결과를 보이기도 한다[17,18]. 벼 는 비소의 생물 유효도가 높은 담수 환원 조건에서 재배되므로 [17] 다른 작물에 비해 비소 농축계수가 크며 다른 곡물과 비 교하면 약 10 배 높은 알곡의 비소 농도를 나타낸다[16,19,20].

한편, Irem 등[21]은 퇴비 처리 시 현미의 비소 농도가 벼 품종에 따라 $24 \%$ 까지 감소하여 유기물 시용에 따른 비소의 유 효도 감소를 보고하였고 Williams 등[7]은 논토양에서 유기물의 비소 용출 촉진과 상반되는 주요 기능으로 토양용액 중의 비소 격리에 따른 생물유효도 저감을 보고하였다.

유기물 시용에 따른 비소의 거동은 환경조건에 따라 다른 결 과를 보이기도 하며, 다수의 배양실험, 또는 포트실험을 통한 연구에서 비소의 유효도 증가가 보고되었고 우리나라의 쌀 섭 취를 통한 위해수준과 폐광산 인근의 비소 오염에 취약한 농경 지 현황을 고려할 때 유기물의 영향에 대한 포장조건에서의 검 증이 필요하다. 본 연구는 유기물 시용이 논토양 내 비소의 용 해도와 작물 흡수에 미치는 영향을 구명함으로써 비소 안전관
리에 유기물이 제한요인으로 작용하는지 여부를 포장조건에서 검증하고자 수행하였으며, 비소 오염에 취약한 농경지에 활용할 수 있는 정보를 제공하고자 한다.

\section{재료 및 방법}

\section{시험포장 조성 및 유기물 처리}

시험에 사용한 토양은 충청남도 공주시 소재 $\mathrm{TC}$ 광산 인근의 비 소 오염도가 높은 논에서 포크레인으로 채취하여 그늘에서 풍 건 후 $4 \mathrm{~mm}$ 체로 걸러 조제하였다. 포장시험을 수행할 논 필 지의 오염되지 않은 토양과 격리된 환경 조성을 위하여 직경 $1 \mathrm{~m}$, 높이 $0.6 \mathrm{~m}$ 의 상-하부가 개방된 원형 플라스틱 구조물 42 개를 시험필지에 $1 \mathrm{~m}$ 간격으로 $40 \mathrm{~cm}$ 깊이로 매설하고 기존의 표층토를 제거한 자리에 시험토양을 $30 \mathrm{~cm}$ 높이로 충진하였다. 시험토양은 비소 농도를 고농도와 저농도로 구분하여 조성하기 위해 채취한 비소 오염 토양과 오염되지 않은 토양을 혼합하여 농도를 조절하였다. 비소 고농도 시험구는 오염토양과 비오염토 양을 $1: 1$ 의 비율로, 저농도 시험구는 $1: 3$ 의 비율로 혼합하고, 설치한 플라스틱 구조물 하부에 각각 $282.5 \mathrm{~kg}$ 의 혼합토양을 충 진하였다. 혼합토양의 비소 농도별 총 비소 농도는 토양오염우 려기준 $25 \mathrm{mg} \mathrm{kg}^{-1}$ [22]을 초과하는 수준인 $53 \mathrm{mg} \mathrm{kg}^{-1}$ (highly polluted, 고농도 비소 토양) 및 $28 \mathrm{mg} \mathrm{kg}^{-1}$ (polluted, 저농도 비소 토양)이었으며 시험구 토양의 화학성 및 중금속 함량은 Table 1 및 2와 같다. 구조물 상단에 개별 호스를 설치하여 물 공급을 하였으며 벼 생육기간 중 물 관리는 관행에 준하여 수 행하였다.

토양에 처리된 유기물의 탄질비가 낮을수록 토양용액으로 용 출되는 비소의 양이 증가한다는 기존의 연구결과[12,14]를 포장 조건에서 검증하기 위하여 토양에 처리할 유기물로 다양한 범 위의 탄질비를 갖는 미강, 볏짚, 돈분퇴비, 우분퇴비, 계분퇴비 및 가축분뇨액비를 선정하였다. Table 3 과 같이 유기물 종류별 로 표토 건조중량의 $1 \%$ 에 해당하는 양을, 가축분뇨액비의 경우 질소함량을 기준으로 벼의 질소 기비량을 시용하고 표토와 충 분히 혼합 후 안정화 과정을 거쳤으며 각 처리구는 3 반복, 임

Table 1 Selected chemical properties of paddy soil

\begin{tabular}{|c|c|c|c|c|c|c|c|c|c|c|}
\hline \multirow{3}{*}{ Soil } & \multirow{3}{*}{$\begin{array}{c}\mathrm{pH} \\
(1: 5)\end{array}$} & \multirow{3}{*}{ 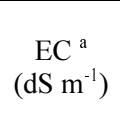 } & \multirow{3}{*}{$\begin{array}{c}\text { Total C } \\
(\%)\end{array}$} & \multirow{3}{*}{$\begin{array}{c}\text { Avail. } \mathrm{P}_{2} \mathrm{O}_{5} \\
\left(\mathrm{mg} \mathrm{kg}^{-1}\right)\end{array}$} & \multirow{3}{*}{$\begin{array}{c}\text { Total N } \\
(\%)\end{array}$} & \multirow{3}{*}{$\begin{array}{c}\mathrm{CEC} \\
\left(\mathrm{cmol}^{+} \mathrm{kg}^{-1}\right)\end{array}$} & \multicolumn{4}{|c|}{ Exchangeable } \\
\hline & & & & & & & $\mathrm{K}$ & $\mathrm{Ca}$ & $\mathrm{Mg}$ & $\mathrm{Na}$ \\
\hline & & & & & & & \multicolumn{4}{|c|}{$\left(\mathrm{cmol}^{+} \mathrm{kg}^{-1}\right)$} \\
\hline High As soil & 6.4 & 0.74 & 1.05 & 80.1 & 0.069 & 14.0 & 0.29 & 4.6 & 1.8 & 0.12 \\
\hline Low As soil & 6.3 & 0.48 & 0.82 & 61.3 & 0.061 & 14.1 & 0.29 & 4.7 & 1.8 & 0.10 \\
\hline
\end{tabular}

${ }^{\mathrm{a}}$ Electrical conductivity

Table 2 Total heavy metal(loid) content of paddy soil $\left(\mathrm{mg} \mathrm{kg}^{-1}\right)$

\begin{tabular}{lcccccc}
\hline \multicolumn{1}{c}{ Element } & As & $\mathrm{Cd}$ & $\mathrm{Pb}$ & $\mathrm{Ni}$ & $\mathrm{Cu}$ \\
\hline High As soil & 53 & 0.1 & 55 & 29 & 25 \\
Low As soil & 28 & 0.1 & 24 & 39 & 29 \\
Worrisome level $^{\mathrm{a}}$ & 25 & 4 & 200 & 100 & 37 & 30 \\
Countermeasure standard $^{\mathrm{b}}$ & 75 & 12 & 600 & 300 & 450 \\
\hline
\end{tabular}

${ }^{\mathrm{a}}$ Worrisome level of soil contamination; ${ }^{\mathrm{b}}$ Standard of countermeasures against soil contamination 
Table 3 Amount added to each experimental plot, $\mathrm{C} / \mathrm{N}$ ratios and heavy metal(loid) content of organic matter used in this study

\begin{tabular}{|c|c|c|c|c|c|c|c|c|c|}
\hline \multirow{2}{*}{ Organic matter } & \multirow{2}{*}{$\begin{array}{l}\text { Amount added } \\
(\mathrm{kg} / 10 \mathrm{a})\end{array}$} & \multirow{2}{*}{$\mathrm{C} / \mathrm{N}$ ratio } & As & $\mathrm{Cd}$ & $\mathrm{Pb}$ & $\mathrm{Cr}$ & $\mathrm{Ni}$ & $\mathrm{Cu}$ & $\mathrm{Zn}$ \\
\hline & & & \multicolumn{7}{|c|}{$\mathrm{mg} \mathrm{kg}^{-1}$ dry weight } \\
\hline Rice bran (RB) & 504 & 130 & 0.03 & 0.002 & 0.04 & 4.3 & 1.7 & 0.9 & 4.0 \\
\hline Rice straw (RS) & 565 & 56.5 & 0.2 & 0.03 & 0.4 & 0.8 & 0.6 & 0.8 & 8.1 \\
\hline Pig manure compost (PM) & 749 & 12.0 & 0.1 & 0.03 & 0.4 & 5.9 & 1.6 & 20.3 & 58.3 \\
\hline Fowls manure compost (FM) & 700 & 11.3 & 0.5 & 0.05 & 3.7 & 17.3 & 3.2 & 20.4 & 90.3 \\
\hline Cattle manure compost (CM) & 886 & 10.4 & 0.4 & 0.04 & 0.9 & 4.2 & 2.3 & 12.0 & 48.5 \\
\hline Swine liquid manure (LM) & $937^{b}$ & 2.3 & 0.1 & 0.02 & 0.05 & 0.3 & 0.4 & 2.3 & 23.6 \\
\hline Standard of compost & - & - & 45 & 5 & 130 & $200-250$ & 45 & $360-400$ & $900-1000$ \\
\hline
\end{tabular}

${ }^{\mathrm{a}} 1 \%$ of surface soil weight on dry weight basis; ${ }^{\mathrm{b}}$ Basal fertilization rate for rice calculated from $\mathrm{N}$ content

의배치법으로 조성하였다. 지표면에서 $3 \mathrm{~cm}$ 높이로 관수 후 1 개월 간 담수 상태를 유지하였고 벼의 시비처방기준[23]에 따 라 보통답의 쌀 목표수량인 $4.8 \mathrm{Mg} \mathrm{ha}^{-1}$ 에 해당하는 질소, 인산 및 칼리의 시비랑을 각각 요소, 용과린 및 염화가리로 시용하 였으며, 파종 후 3 주 간 육묘한 벼를 재식밀도 $25 \mathrm{~cm} \times 15 \mathrm{~cm}$, 1 주 3 본으로 처리구 당 17 주를 이앙하였다. 벼 생육기간 중 토 양용액을 채취하기 위해 토양용액 채취기(Macro rhizon, rhizosphere, the Netherlands)를 각 처리구의 지표면으로부터 13 $\mathrm{cm}$ 깊이에 설치하였다.

\section{토양화학성 분석}

토양시료는 토양화학분석법[24]에 따라 음건하여 $2 \mathrm{~mm}$ 체로 거 른 후 $\mathrm{pH}$ (1:5), 전기전도도, 유기물 함량, 유효인산, 총 질소 함량 등을 분석하였다. 중금속 총 함량은 토양오염공정시험기준 [25]에 따라 환류냉각장치를 이용하여 전처리 후 ICP-MS (7700, Agilent Technologies, Tokyo, Japan)로 분석하였다. 중 금속 분석의 신뢰도를 검정하기 위해 토양 인증표준물질(BAM $\mathrm{U} 112 \mathrm{a}$, Berlin, Germany)로 분석 정확도를 검정하였으며 토양 오염공정시험기준을 만족하는 정확도 $85-110 \%$ 조건에서 분석 을 수행하였다.

\section{토양용액 분석}

Macro rhizon에 $20 \mathrm{~mL}$ 주사기를 연결하여 주기적으로 토양용 액을 채취 후 $\mathrm{pH}$, 비소, 용존유기탄소(Dissolved Organic Carbon, $\mathrm{DOC})$, 철 및 망간의 농도를 분석하였으며 비소, 철, 및 망간 분석은 ICP-AES (Integra XL, GBC, Braeside, Australia)를, 용존유기탄소는 TOC 분석기(LCPH, Shimadzu, Kyoto, Japan) 를 이용하여 분석하였다.

\section{식물체 및 유기물 분석}

현미의 비소 및 유기물의 중금속 함량 분석은 농촌진흥청 농업 과학기술 연구조사분석기준[23]에 따라 microwave digestion system (ETHOS 1, Milestone IT, Sorisole, Italy)을 이용하여 전처리 후 ICP-MS (7700, Agilent Technologies, Japan)로 분 석하였다. 인증표준물질인 쌀 분말(ERM IRMM-804, Geel, Belgium)을 이용하여 분석 정확도를 검정하였으며 정확도 85$115 \%$ 를 만족하는 조건에서 시료중의 중금속 분석을 수행하였 다. 유기물의 탄소 및 질소 분석은 $\mathrm{CN}$ Analyzer (Vario Max, Elementar, Langenselbold, Germany)를 이용하여 분석하였으며
유기물 종류에 따른 중금속 함량 및 탄질비는 Table 3과 같다.

\section{통계 분석}

유기물 처리가 토양 중 비소의 용해도 및 벼의 비소 흡수에 미 치는 영향을 분석하기 위하여 통계 패키지 SAS EG (ver 7.1) 를 이용하여 상관분석 및 분산분석을 수행하였다.

\section{결과 및 고찰}

\section{유기물 시용에 따른 토양환경 변화}

시험포장 조성 후 탄질비가 서로 다른 유기물(미강, 볏짚, 돈분 퇴비, 우분퇴비, 계분퇴비 및 가축분뇨액비)을 토양 중 총 비소 농도가 $53 \mathrm{mg} \mathrm{kg}^{-1}$ (고농도) 및 $28 \mathrm{mg} \mathrm{kg}^{-1}$ (저농도)인 시험포장 토양에 처리구별로 시용 후 벼 생육기간 중 토양용액의 비소 농도를 모니터링한 결과, 고농도 비소 토양의 경우 벼 이앙 후 55 일(유수형성기 초기)-110일(등숙기) 기간의 비소 농도는 유기 물 처리구에서 평균 $0.44-1.15 \mathrm{mg} \mathrm{L}^{-1}$ 의 범위로 무처리구의 평 균 $0.42-0.66 \mathrm{mg} \mathrm{L}^{-1}$ 에 비해 최대 약 1.7 배의 농도를 나타냈다. 이앙 후 경과일수에 따라 돈분퇴비, 가축분뇨액비, 미강 처리에 서 무처리구와 유의한 농도 차이를 보였으며 특히, 돈분퇴비의 경우 이앙 후 55일과 77 일에 평균 $1.07-1.15 \mathrm{mg} \mathrm{L}^{-1}$ 로 다른 처 리에 비해 상대적으로 높은 농도를 나타내었다(Fig. 1). 이와 같 은 결과는 이앙 후 67-112일 기간 유기물 처리구의 토양용액 중 비소 평균 농도가 무처리구의 $0.2-1.0 \mathrm{mg} \mathrm{L}^{-1}$ 와 비교하여 0.5-3.6 mg L $\mathrm{L}^{-1}$ 로 높음을 보고한 포트실험 결과[18]와 비교할 때 농도 차이는 다소 낮았으나 유사한 유기물 처리의 영향을 보여 주었다. 시간 경과에 따른 유기물 처리구의 토양용액 중 비소 의 평균 농도는 이앙 후 55 일의 $0.88 \mathrm{mg} \mathrm{L}^{-1}$ 에서 이앙 후 110 일의 $0.57 \mathrm{mg} \mathrm{L}^{-1}$ 로 감소하는 경향이었다.

같은 기간 저농도 토양의 경우 토양용액 중 평균 비소 농도 는 유기물 처리구에 따라 $0.12-0.50 \mathrm{mg} \mathrm{L}^{-1}$ 로 무처리구의 0.14 $0.30 \mathrm{mg} \mathrm{kg}^{-1}$ 에 비해 다소 높은 경향이었으나 유의한 차이는 나 타나지 않았으며, 처리구별로 비교 시 고농도 토양의 토양용액 중 비소 농도는 저농도 토양의 약 1.9-3.6배로 상대적으로 높은 농도를 나타내었다. 시간 경과에 따른 저농도 토양 유기물 처 리구의 토양용액 중 비소의 평균 농도는 이앙 후 55 일의 0.35 $\mathrm{mg} \mathrm{L}^{-1}$ 에서 이앙 후 110 일의 $0.14 \mathrm{mg} \mathrm{L}^{-1}$ 로 점차 감소하였다 (Fig. 1). 


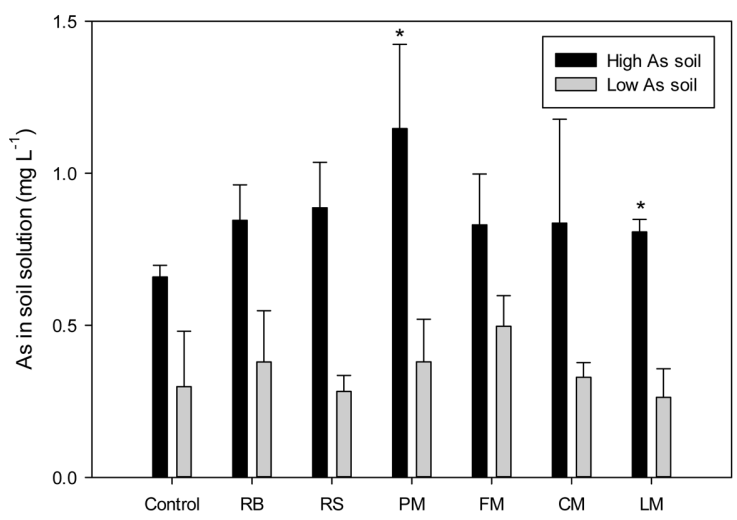

(A) As content in soil solutions at 55 days after rice planting

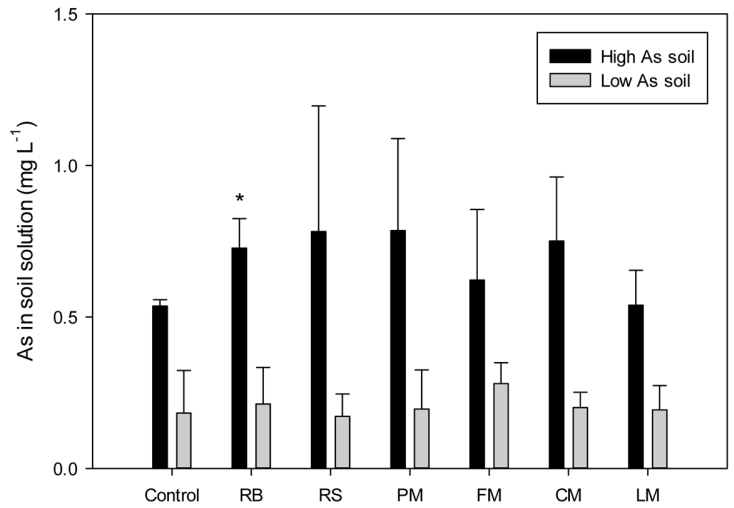

(C) As content in soil solutions at 93 days after rice planting

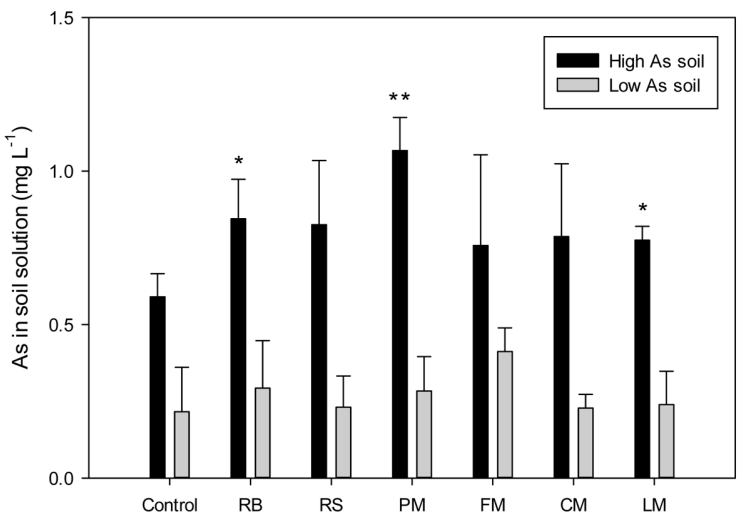

(B) As content in soil solutions at 77 days after rice planting

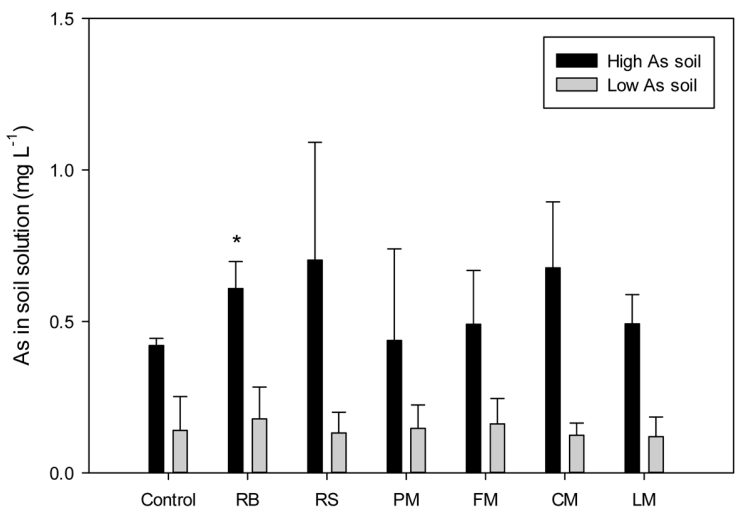

(D) As content in soil solutions at 110 days after rice planting

Fig. 1 As content in soil solutions from each treatment after rice planting. Values are presented as the mean $\pm \operatorname{SD}(n=3)$. Asterisks indicate significant differences compared to the control value for given group at ${ }^{*} p<0.05$ and ${ }^{* *} p<0.01$ levels, respectively

Table 4 Pearson correlation coefficients between total As and Fe, Mn, and DOC in soil solution from the high and low As soils for each day after rice planting

\begin{tabular}{ccccccc}
\hline \hline \multirow{2}{*}{ DAP $^{\mathrm{a}}$} & \multicolumn{2}{c}{$\mathrm{Fe}$} & \multicolumn{2}{c}{ Mn } & \multicolumn{2}{c}{ DOC $^{\mathrm{C}}$} \\
\cline { 2 - 7 } & High As soil & Low As soil & High As soil & Low As soil & High As soil & Low As soil \\
\hline 55 & $0.823^{* * *}$ & $0.881^{* * *}$ & $\mathrm{~ns}$ & $\mathrm{~ns}$ & $\mathrm{~ns}$ & $\mathrm{~ns}$ \\
77 & $0.841^{* * *}$ & $0.905^{* * *}$ & $\mathrm{~ns}$ & $\mathrm{~ns}$ & $\mathrm{~ns}$ & $-0.439^{*}$ \\
93 & $0.753^{* * *}$ & $0.865^{* * *}$ & $0.461^{*}$ & $\mathrm{~ns}$ & $0.725^{* * *}$ & $\mathrm{~ns}$ \\
110 & $0.785^{* * *}$ & $0.864^{* * *}$ & $0.577^{* *}$ & $\mathrm{~ns}$ & $\mathrm{~ns}$ & $\mathrm{~ns}$ \\
Whole period & $0.756^{* * *}$ & $0.847^{* * *}$ & $0.544^{* * *}$ & $0.511^{* * *}$ & $0.477^{* * *}$ & $\mathrm{~ns}$ \\
\hline
\end{tabular}

${ }^{\mathrm{a}}$ Days after rice planting; ${ }^{\mathrm{b}} \mathrm{Not}$ significant; ${ }^{\mathrm{C}}$ Dissolved organic carbon. Asterisks indicate significant differences at ${ }^{*} p<0.05,{ }^{* *} p<0.01$ and ${ }^{* * *} p<0.001$ levels, respectively

고농도 비소 토양에서 이앙 후 $55-110$ 일 기간의 토양용액 중 비소 농도는 토양용액의 철 농도와 고도의 유의한 정의 상관관 계를 보였고 망간과는 이앙 후 93-110일 기간에 유의한 정의 상관관계를, 용존유기탄소(DOC)와는 이앙 후 93일에 유의한 정 의 상관관계를 보였으며, 저농도 토양의 경우에는 전체 기간에 서 철과 고도로 유의한 정의 상관 관계를 보였다(Table 4, Fig. 2). 담수 토양에서 용출된 비소와 철의 높은 상관 관계 $[12,15,18,26]$ 는 미생물이 유기물을 탄소원으로 이용, 산소를 소 모함에 따라 산화환원전위가 낮아지고[8] 그 결과 철 (수)산화 물의 환원적 용해로 비소가 용출[9-13] 되었기 때문으로 판단된
다. 고농도 비소 토양에서 이앙 후 93일에 토양용액 중 비소와 $\mathrm{DOC}$ 사이에 유의한 정의 상관을 보인 것은 다른 연구결과 $[18,30]$ 와 유사하며, 용존 유기물이 비소와 가용성 착물을 형성 하거나[7] 유기물이 토양 표면에 있는 이온교환 자리의 비소를 탈착[31]하였기 때문으로 판단된다. 그러나 저농도 비소 토양에 서는 고농도 토양에서 나타난 토양용액 중 비소와 망간 및 $\mathrm{DOC}$ 사이의 정의 상관관계는 관찰되지 않았으며(Table 4), 토 양용액 중 비소와 DOC의 농도분포를 벼의 생육 시기별 구분 없이 통합하여 상관분석을 수행한 결과 고농도 토양의 경우 고 도로 유의한 정의 상관을 보인 반면, 저농도 토양의 경우에는 


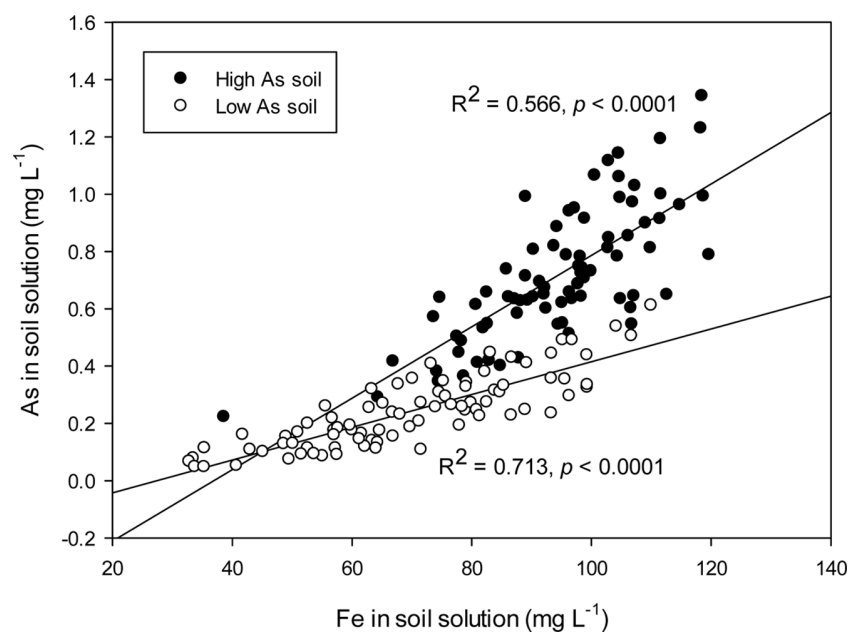

Fig. 2 Linear regression between $\mathrm{As}$ and $\mathrm{Fe}$ in soil solution from 55 to 110 days after rice planting

상관성이 나타나지 않았다(Table 4, Fig. 3). 망간 (수)산화물과 결합한 비소는 철 (수)산화물의 경우보다 낮은 산화환원전위에 서 망간 (수)산화물이 환원[27] 될 때 담수 토양의 용액으로 용 출되어 유효도가 증가한다[28,29]. 고농도 비소 토양에서 토양 용액 중 비소와 망간 농도 사이에 이앙 후 93 일 이후에 유의 한 정의 상관관계를 보인 것은 이 시기의 환원전위가 망간 (수) 산화물의 환원을 유발하는 수준으로 더 낮아짐에 따라 결합 상 태에 있던 비소가 용출된 결과로 추측되며, 저농도 비소 토양 의 경우 토양용액 중 비소와 망간의 농도분포를 시기별 구분없 이 통합하여 상관분석을 수행한 결과 고농도 토양과 마찬가지 로 고도로 유의한 정의 상관을 보였다(Table 4). 이와 같은 결 과로부터 유기물 시용에 따른 논토양 중 비소의 용출에는 철 및 망간 (수)산화물의 환원적 용해가 비소와 가용성 착물을 형 성하거나[7] 토양 표면의 이온교환에 의해 비소를 탈착하는[31] $\mathrm{DOC}$ 보다 상대적으로 큰 영향을 미친 것으로 판단된다.

시간 경과에 따른 고농도 토양 무처리구 토양용액의 $\mathrm{pH}$ 는 이 앙 후 55 일의 6.6 에서 이앙 후 110 일의 6.8 로 미미하게 상승하 였고 유기물 처리구의 $\mathrm{pH}$ 는 같은 기간 6.5-6.7에서 6.7-6.8로 상승하여 처리구 사이에 큰 차이는 나타나지 않았다. 저농도 토 양의 경우에도 무처리구 토양용액의 $\mathrm{pH}$ 는 이앙 후 55일의 6.7 에서 이앙 후 110 일의 6.9 로 소폭 상승하였고 유기물 처리구의 $\mathrm{pH}$ 는 같은 기간에 6.6-6.7에서 6.8로 상승하여 처리구 사이에 큰 차이는 나타나지 않았다. Marin 등[32]은 $\mathrm{pH}$ 가 낮을수록 토 양 내 용존 비소의 농도는 증가한다고 하였으며, 본 연구에서 도 처리구의 $\mathrm{pH}$ 변이는 크지 않았으나 벼 이앙 후 55-110일 기간에 $\mathrm{pH}$ 와 토양용액의 비소 사이에 유의한 음의 상관을 보 였다(Pearson $\mathrm{r}=-0.573 \sim-0.719, p=0.004 \sim 0.032$ ).

한편, 유기물의 탄질비와 토양용액의 비소 농도 사이에는 상 관 관계가 나타나지 않아 탄질비와 비소 간 음의 상관 관계를 보고한 연구[12,14]와는 다른 결과를 나타내었다.

\section{유기물 시용에 따른 현미의 비소 농도}

현미의 비소 평균 농도는 고농도 비소 토양의 경우 무처리구의 $0.37 \mathrm{mg} \mathrm{kg}^{-1}$ 과 비교하여 가축분뇨액비 처리에서는 $0.37 \mathrm{mg} \mathrm{kg}^{-1}$

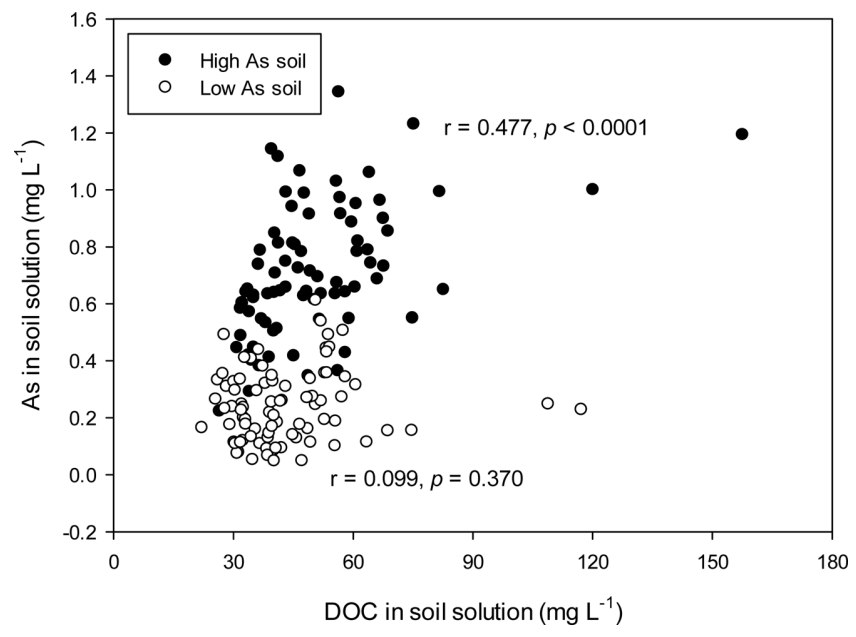

Fig. 3 Pearson correlation between As and DOC in soil solution from 55 to 110 days after rice planting

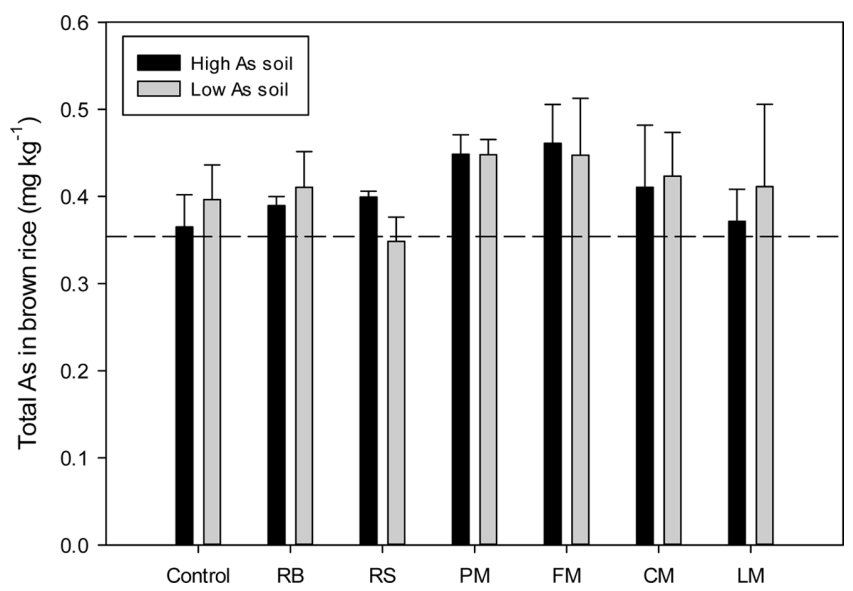

Fig. 4 Total As content in brown rice form each treatment. Reference line indicates the safe limit of inorganic As in brown rice $\left(0.354 \mathrm{mg} \mathrm{kg}^{-1}\right)$ used for the screening value of total As content in brown rice for inorganic As analysis in safety inspection procedure

으로 동일하였다(Fig. 4). 그러나, 미강, 볏짚, 퇴비 처리에서는 $0.39-0.46 \mathrm{mg} \mathrm{kg}^{-1}$ 으로 다소 높은 경향이었고 계분퇴비와 돈분퇴 비 처리에서는 $0.45-0.46 \mathrm{mg} \mathrm{kg}^{-1}$ 으로 높게 나타났으며 대부분의 처리구에서 코덱스의 현미 중 무기비소 기준인 $0.35 \mathrm{mg} \mathrm{kg}^{-1}$ [33]을 초과하였다. 무처리구와 유기물 처리구의 토양용액 중 비 소 농도는 유의한 차이를 보인 반면(Fig. 1), 현미 중 비소 농 도는 유기물 처리에 따른 유의한 차이가 나타나지 않았으며, 현 미와 토양용액 중 비소 농도 사이의 상관 관계 또한 관찰되지 않았다. 따라서 유기물 처리에 따른 현미의 비소 농도는 대조 구보다 약 2배 이상 유의한 차이가 있고 $[17,18]$ 유수형성기-등 숙기 초기의 토양용액 중 비소 농도와 고도의 상관성이 있음을 보고한 Yoo 등[18]과는 다른 결과를 보였다.

저농도 비소 토양의 경우 현미 중 비소는 무처리구의 0.40 $\mathrm{mg} \mathrm{kg}^{-1}$ 과 비교하여 볏짚 처리에서는 $0.35 \mathrm{mg} \mathrm{kg}^{-1}$ 으로 다소 낮 았으나 미강, 퇴비, 가축분뇨액비 처리에서는 $0.41-0.45 \mathrm{mg} \mathrm{kg}^{-1}$ 으로 다소 높은 경향이었다(Fig. 4). 고농도 토양의 경우와 같 


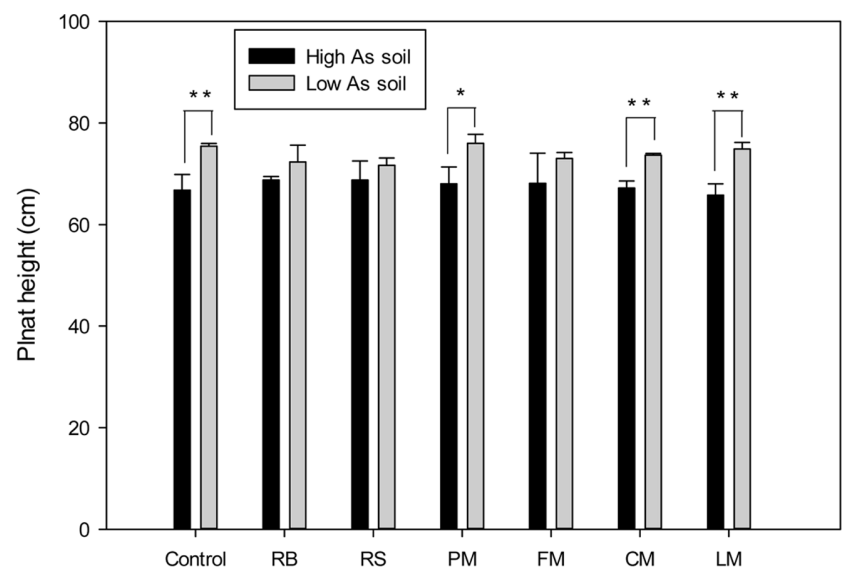

(A) Height of rice plant at 59 days after rice planting

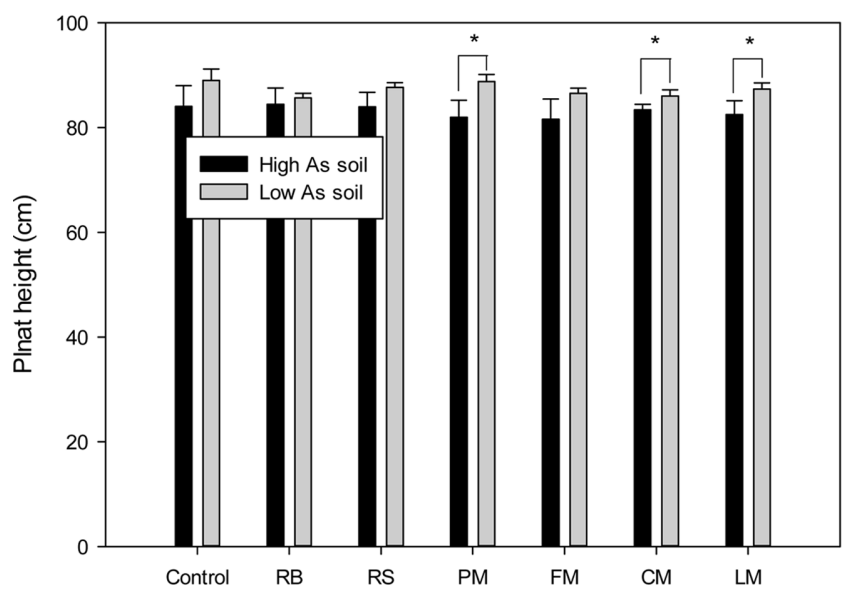

(B) Height of rice plant at 94 days after rice planting

Fig. 5 Height of rice plant at 59 and 94 days after rice planting. Values are presented as the mean $\pm \mathrm{SD}(\mathrm{n}=3)$. Asterisks indicate significant differences for given group at $* p<0.05$ and ${ }^{* *} p<0.01$ levels, respectively

이 계분퇴비와 돈분퇴비 처리에서 $0.45 \mathrm{mg} \mathrm{kg}^{-1}$ 으로 가장 높게 나타났고 볏짚을 제외한 모든 처리에서 현미 중 무기비소 기준 을 초과하였다. 무처리구와 유기물 처리구의 현미 중 비소 농 도 사이에 유의한 차이는 없었으며 현미와 토양용액의 비소 농 도 사이에 상관관계는 나타나지 않았다.

고농도 비소 토양의 비소 농도는 $53 \mathrm{mg} \mathrm{kg}^{-1}$ 으로 저농도 토 양의 $28 \mathrm{mg} \mathrm{kg}^{-1}$ 보다 약 2배 높고(Table 2) 토양용액의 비소는 $0.42-1.15 \mathrm{mg} \mathrm{L}^{-1}$ 로 저농도 토양의 $0.12-0.50 \mathrm{mg} \mathrm{L}^{-1}$ 에 비해 약 2-3.6배 높았으나(Figs. 1 and 2) 고농도 비소 토양에서 수확한 현미의 비소 평균 농도는 볏짚 처리구를 제외할 경우 저농도 토양의 경우보다 낮거나 유사한 농도를 나타내었다. 이는 유수 형성기(이앙 후 59일 경)와 등숙기 초기(이앙 후 94일 경)의 벼 생육이 일부 처리구에서 유의한 차이가 있는 것으로 보아(Fig. 5) 고농도 비소 토양에서 토양용액의 높은 비소 농도로 인해 벼 의 생육이 억제되는 한편, 비소에 대한 내성 발현에 따른 비소 의 흡수 감소[34], 또는 알곡으로의 이행이 감소한 결과로 판단 되었다.
벼에 흡수된 대부분의 비소는 뿌리에 보유되며[32] 식물체 내 비소의 뿌리에서 줄기 및 알곡으로의 이행은 낮으나 식물 종 내 변이는 매우 크다[35]. Panaullah 등[36]은 비소 농도가 10$70 \mathrm{mg} \mathrm{kg}$-1인 일련의 토양에서 벼 재배 시 비소 농도가 증가할 수록 수량이 감소하고 볏짚의 비소 농도는 증가하는 반면, 백 미의 비소 농도는 토양 및 토양용액의 비소 농도와 상관성이 없거나 비소의 독성 영향으로 선형적으로 감소함을 보고하였다. 또한, 같은 토양에서 비소의 독성을 감소시키기 위하여 보다 호 기적인 조건에서 벼를 재배할 경우 토양의 비소 농도가 증가할 수록 알곡의 비소 농도는 증가하여[37] 알곡의 비소 농도가 비 소의 독성에 영향을 받음을 보여주었다.

한편, 5 가 무기비소(arsenate)는 인산 수송체(phosphate transporter) 에 의해 벼에 흡수되며[38] 인산은 식물의 비소에 대한 친화력 과 비소 흡수율을 감소시킨다[32,39]. 저농도 비소 토양의 유효 인산 함량은 $61 \mathrm{mg} \mathrm{kg}^{-1}$ 으로 논토양의 적정 범위인 $80-120 \mathrm{mg}$ $\mathrm{kg}^{-1}$ [40]에 못 미치고 고농도 토양의 $80 \mathrm{mg} \mathrm{kg}^{-1}$ 에 비해 낮으 므로(Table 1) 벼의 비소 흡수 과정에서 고농도 토양에 비해 인 과의 흡수 경쟁이 감소한 결과, 대부분의 처리구에서 저농도 비 소 토양의 현미 중 비소 농도가 고농도 토양의 경우보다 높거 나 유사한 농도를 나타낸 것으로 판단되며, Jiang 등[4]은 토양 의 $\mathrm{pH}$ 가 5 보다 높을 때 유효인산과 벼 알곡의 비소 사이에는 유의한 음의 상관을 보이며 인이 벼의 비소 흡수를 억제한다고 하였다.

\section{초록}

유기물 시용이 논토양 내 비소의 용해도와 벼의 비소 흡수에 미치는 영향을 구명하기 위한 포장시험을 수행하였다. 유기물(미 강, 볏짚, 돈분퇴비, 우분퇴비, 계분퇴비 및 가축분뇨액비)을 토 양 중 총 비소 농도가 $53 \mathrm{mg} \mathrm{kg}^{-1}$ (highly polluted, 고농도) 및 $28 \mathrm{mg} \mathrm{kg}^{-1}$ (polluted, 저농도)인 논토양에 시용한 결과, 고농도 비소 토양의 경우 벼의 유수형성기-등숙기 기간 토양용액 중 비 소 농도는 돈분퇴비, 가축분뇨액비 및 미강 처리에서 0.61-1.15 $\mathrm{mg} \mathrm{L}^{-1}$ 로 무처리구의 $0.42-0.66 \mathrm{mg} \mathrm{L}^{-1}$ 에 비해 최대 약 1.7 배의 유의한 농도 차이를 보였다. 저농도 비소 토양의 토양용액 중 비소 농도는 $0.12-0.50 \mathrm{mg} \mathrm{L}^{-1}$ 로 고농도 토양에 비해 약 50 $70 \%$ 낮았으며 무처리구와 유의한 차이는 없었다. 토양용액 중 비소 농도의 증가는 비소와 결합한 철 (수)산화물의 환원적 용 해로 인한 결과로 보이며 유기물의 탄질비와 비소 농도 사이에 는 상관 관계가 나타나지 않았다. 고농도 및 저농도 비소 토양 에서 수확한 현미의 비소 평균 농도는 $0.35-0.46 \mathrm{mg} \mathrm{kg}^{-1}$ 범위 로 대부분의 처리에서 무기비소에 대한 코덱스의 안전기준인 $0.35 \mathrm{mg} \mathrm{kg}^{-1}$ 을 초과하였고 토양 오염도에 따른 유의한 차이는 없었으며, 무처리구에 비해 유기물 처리구의 농도가 높은 경향 이었다. 현미 중 비소와 토양용액 중 비소 농도와의 뚜렷한 상 관성은 나타나지 않았으며, 이는 비소에 대한 벼의 내성 발현 에 따른 비소의 흡수 감소, 또는 알곡으로의 이행이 감소한 결 과로 추측되었다. 그러나, 유기물 시용 후 토양 내 비소의 용해 도 증가와 대부분의 유기물 처리에서 현미 중 비소 농도의 증 가 경향이 나타나 토양의 비소 농도가 높은 경우 유기물 시용 시 적정량 시용 등 주의가 필요할 것으로 판단된다. 
Keywords 비소 · 유기물 · 벼 · 토양 - 용해도

Acknowledgment The work was supported by the Rural Development Administration of Korea (Project - PJ01092302).

\section{References}

1. National Institute of Food and Drug Safety Evaluation (NIFDS) (2021) Integrated risk assessment of heavy metals (5 elements). National Institute of Food and Drug Safety Evaluation, Cheongju

2. Ministry of Food and Drug Safety (MFDS) (2016) Korean Food Standards Codex. Ministry of Food and Drug Safety, Cheongju

3. Ministry of Food and Drug Safety (MFDS) (2017) Principal of food quality standards establishment. Ministry of Food and Drug Safety, Cheongju

4. Jiang W, Hou Q, Yang Z, Zhong C, Zheng G, Yang Z, Li J (2014) Evaluation of potential effects of soil available phosphorus on soil arsenic availability and paddy rice inorganic arsenic content. Environ Pollut 188: 159-165. doi: 10.1016/j.envpol.2014.02.014

5. Mine Reclamation Corporation (MIRECO) (2020) Annual report of Mine Reclamation Corporation. Mine Reclamation Corporation, Wonju

6. National Institute of Agricultural Sciences (NIAS) (2018) Development of Integrated System of Monitoring and Risk Assessment of Hazardous Substances in Agricultural Sector. National Institute of Agricultural Sciences, Wanju

7. Williams PN, Zhang H, Davison W, Meharg AA, Hossain M, Norton GJ, Brammer H, Islam MR (2011) Organic matter-solid phase interactions are critical for predicting arsenic release and plant uptake in Bangladesh paddy soils. Environ Sci Technol 45: 6080-6087. doi: 10.1021/ es 2003765

8. Harvey CF, Swartz CH, Badruzzaman ABM, Keon-Blute N, Yu W, Ali MA, Jay J, Beckie R, Niedan V, Bradandert D, Oates PM, Ashfaque KN, Islam S, Hemond HF, Ahmed MF (2002) Arsenic mobility and groundwater extraction in Bangladesh. Science 298: 1602-1606. doi: 10.1126/science. 1076978

9. Masscheleyn PH, Delaune RD, Patrick Jr. WH (1991) Effect of redox potential and $\mathrm{pH}$ on arsenic speciation and solubility in a contaminated Soil. Environ Sci Technol 25: 1414-1419. doi: 10.1021/es00020a008

10. Rowland HAL, Boothman C, Pancost R, Gault AG, Polya DA, Lloyd JR (2009) The role of indigenous microorganisms in the biodegradation of naturally occurring petroleum, the reduction of iron, and the mobilization of arsenite from West Bengal aquifer sediments. J Environ Qual 38: 1598-1607. doi:10.2134/jeq2008.0223

11. Signes-Pastor A, Burló F, Mitra K, Carbonell-Barrachina AA (2007) Arsenic biogeochemistry as affected by phosphorus fertilizer addition, redox potential and $\mathrm{pH}$ in a west Bengal (India) soil. Geoderma 137: 504-510. doi: 10.1016/j.geoderma.2006.10.012

12. Suda A, Baba K, Yamaguchi N, Akahane I, Makino T (2015) The effects of soil amendments on arsenic concentrations in soil solutions after longterm flooded incubation. Soil Sci Plant Nutr 61: 1-11. doi: 10.1080/ 00380768.2015.1006119

13. van Geen A, Rose J, Thoral S, Garnier JM, Zheng Y, Bottero JY (2004) Decoupling of As and Fe release to Bangladesh groundwater under reducing conditions. Part II: evidence from sediment incubations. Geochim Cosmochim Acta 68: 3475-3486. doi: 10.1016/j.gca.2004. 02.014

14. Solaiman ARM, Meharg AA, Gault AG, Charnock JM (2009) Arsenic mobilization from iron oxyhydroxides is regulated by organic matter carbon to nitrogen $(\mathrm{C}: \mathrm{N})$ ratio. Enviro Int 35: 480-484. doi: 10.1016/ j.envint.2008.07.024

15. Yamaguchi N, Nakamura T, Dong D, Takahashi Y, Amachi S, Makino T (2011) Arsenic release from flooded paddy soils is influenced by speciation, Eh, pH, and iron dissolution. Chemosphere 83: 925-932. doi: 10.1016/j.chemosphere.2011.02.044

16. Honma T, Ohba H, Kaneko-Kadokura A, Makino T, Nakamura K, Katou $\mathrm{H}$ (2016) Optimal soil $\mathrm{Eh}, \mathrm{pH}$, and water management for simultaneously minimizing arsenic and cadmium concentrations in rice grains. Environ Sci Technol 50: 4178-4185. doi: 10.1021/acs.est. $5 \mathrm{~b} 05424$

17. Norton GJ, Adomako EE, Deacon CM, Carey AM, Price AH, Meharg AA (2013) Effect of organic matter amendment, arsenic amendment and water management regime on rice grain arsenic species. Environ Pollut 177: 38-47. doi: 10.1016/j.envpol.2013.01.049

18. Yoo JH, Lee JW, Yoon JH, Kim MH, Kim SI, Kim SC (2020) Effect of organic matter of various $\mathrm{C}: \mathrm{N}$ ratios on the solubility of arsenic, manganese, and iron in paddy soil and on arsenic availability to plants. Environ Anal Health Toxicol 23: 211-221. doi: 10.36278/jeaht.23.4.211

19. Williams PN, Villada A, Deacon C, Raab A, Figuerola J, Green AJ, Feldmann J, Meharg AA (2007) Greatly enhanced arsenic shoot assimilation in rice leads to elevated grain levels compared to wheat and barley. Environ Sci Technol 41: 6854-6859. doi: 10.1021/es070627i

20. Xu XY, McGrath SP, Meharg AA, Zhao FJ (2008) Growing rice aerobically markedly decreases arsenic accumulation. Environ Sci Technol 42: 5574-5579. doi: 10.1021/es800324u

21. Irem S, Islam E, Maathuis FJM, Niazi NK, Li T (2019) Assessment of potential dietary toxicity and arsenic accumulation in two contrasting rice genotypes: effect of soil amendments. Chemosphere 225: 104-114. doi: 10.1016/j.chemosphere.2019.02.202

22. Ministry of Environment (MOE) (2018) Soil Environmental Conservation Act. Ministry of Environment, Sejong

23. Rural Development Administration (RDA) (2012) Research, survey and analysis standard for agricultural science and technology. Rural Development Administration, Jeonju

24. National Institute of Agricultural Sciences (NIAS) (2010) Methods of soil chemical analysis. National Institute of Agricultural Sciences, Wanju

25. Ministry of Environment (MOE) (2010) Official methods of soil analysis for polluted soils. Ministry of Environment, Sejong

26. Weber FA, Hofacker AF, Voegelin A, Kretzschmar R (2010) Temperature dependence and coupling of iron and arsenic reduction and release during flooding of a contaminated soil. Environ Sci Technol 44: 116-122. doi: 10.1021/es902100h

27. Reddy KR, DeLaune RD (2008) Biogeochemistry of wetlands: science and applications. CRC Press, Boca Raton

28. Fitz WJ, Wenzel WW (2002) Arsenic transformations in the soilrhizosphere-plant system: fundamentals and potential application to phytoremediation. J Biotechnol 99: 259-278. doi: 10.1016/S01681656(02)00218-3

29. Takahashi Y, Minamikawa R, Hattori KH, Kurishima K, Kihou N, Yuita $\mathrm{K}$ (2004) Arsenic behavior in paddy elds during the cycle of flooded and non-flooded periods. Environ Sci Technol 38: 1038-1044. doi: 10.1021/ es034383n

30. Shaheen SM, Rinklebe J, Rupp H, Meissner R (2014) Lysimeter trials to assess the impact of different flood-dry-cycles on the dynamics of pore water concentrations of $\mathrm{As}, \mathrm{Cr}$, Mo and $\mathrm{V}$ in a contaminated floodplain soil. Geoderma 228-229: 5-13. doi: 10.1016/j.geoderma.2013.12.030

31. Weng L, Van Riemsdijk WH, Hiemstra T (2009) Effects of fulvic and humic acids on arsenate adsorption to goethite: experiments and modelling. Environ Sci Technol 43: 7198-7204. doi: 10.1021/es9000196

32. Marin AR, Masscheleyn PH, Patrick Jr WH (1993) Soil redox-pH stability of arsenic species and its influence on arsenic uptake by rice. Plant Soil 152: 245-253. doi: 10.1007/BF00029094

33. Codex Alimentarius Commission (CAC). 2016. Report on thirty-ninth session of Codex. Codex Alimentarius Commission, Rome

34. Meharg AA (2004) Arsenic in rice - understanding a new disaster for South-East Asia. TRENDS in Plant Science. doi: 10.1016/j.tplants. 2004.07.002

35. Finnegan PM, Chen W (2012) Arsenic toxicity: the effects on plant metabolism. Front Physio 3: 182. doi: 10.3389/fphys.2012.00182 
36. Meharg AA, Bailey J, Breadmore K, Macnair MR (1994) Biomass allocation, phosphorus nutrition and vesicular-arbuscular mycorrhizal infection in clones of Yorkshire Fog, Holcus lanatus L. (Poaceae) that differ in their phosphate uptake kinetics and tolerance to arsenate. Plant Soil 160: 11-20. doi: 10.1007/BF00150341

37. Duxbury JM, Panaullah G (2007) Remediation of arsenic for agriculture sustainability, food security and health in Bangladesh. FAO, Rome

38. Panaullah GM, Alam T, Hossain MB, Loeppert RH, Lauren JG, Meisner CA, Ahmed ZU, Duxbury JM (2009) Arsenic toxicity to rice (Oryza sativa L.) in Bangladesh. Plant Soil 317: 31-39. doi: 10.1007/s11104008-9786-y

39. Meharg AA, Macnair MR (1990) An altered phosphate uptake system in arsenate-tolerant Holcus lanatus L. New Phytol 116: 29-35. doi: 10.1111/j.1469-8137.1990.tb00507.x

40. National Institute of Agricultural Sciences (NIAS) (2013) Monitoring project on agro-environmental quality in Korea. National Institute of Agricultural Sciences, Wanju 